\title{
Agricultural crops in the diet of bearded capuchin monkeys, Cebus libidinosus Spix (Primates: Cebidae), in forest fragments in southeast Brazil
}

\author{
Carlos Henrique de Freitas ${ }^{1,2}$; Eleonore Z. F. Setz ${ }^{3}$; Alba R. B. Araújo ${ }^{4}$ \& Nivar Gobbi ${ }^{2}$ \\ ${ }^{1}$ Corresponding author. Instituto de Ciências da Saúde, Centro Universitário do Planalto de Araxá. Avenida Amazonas 777, \\ 38180-084 Araxá, Minas Gerais, Brazil. E-mail: biologiatg@uol.com.br \\ ${ }^{2}$ Curso de Pós-Graduação em Zoologia, Departamento de Zoologia, Instituto de Biociências, Universidade Estadual Paulista. \\ Avenida 24A 1515, 13506-900 Rio Claro, São Paulo, Brasil. \\ ${ }^{3}$ Departamento de Zoologia, Instituto de Biologia, Universidade Estadual de Campinas. Caixa Postal 6109, \\ 13083-970 Campinas, São Paulo, Brasil. \\ ${ }^{4}$ Departamento de Biologia, Universidade de Franca. Avenida Doutor Armando Sales de Oliveira 201, 14404-600 Franca, \\ São Paulo, Brasil.
}

\begin{abstract}
Capuchin monkeys occupy a wide range of habitats where they feed on fruits, arthropods, and vertebrates. Their large home ranges (80-900 ha) suggest that living in forest fragments may challenge their adaptability. We identified and quantified the main food items of Cebus libidinosus Spix, 1823 in forests fragments (100 ha) in southeastern Brazil. We recorded the feeding activities of two groups using scan sampling over a 13-month period. The diet was composed of fruits, crops, animal prey, seeds, plant matter and undetermined. Fruit was eaten more in the wet season than in the dry season, and maize and sugar cane consumption peaked in the early dry season. The proportion of fruit in the diet was positively correlated with fruiting intensity of zoochorous trees. The plant diet included 54 species, with maize, Rhamnidium elaeocarpus, Acrocomia aculeata, Guazuma ulmifolia and Cariniana, being most important. Although dietary composition and diversity were similar to capuchins in larger forest fragments, feeding on crops attained higher percentages at times when zoochorous fruit production was low in fragments.
\end{abstract}

KEY WORDS. Franca; gallery forest fragments; maize; sugar cane.

RESUMO. Cultivares na dieta de macacos-prego barbados, Cebus libidinosus Spix (Primates: Cebidae), em fragmentos florestais no sudeste do Brasil. Macacos-prego ocupam uma vasta gama de ambientes onde alimentam-se de frutos, artrópodes e vertebrados. Suas grandes áreas de vida (80-900 ha) sugerem que viver em fragmentos florestais pode ser um desafio a sua adaptabilidade. Foram identificados e quantificados os principais itens alimentares de Cebus libidinosus Spix, 1823 em fragmentos florestais (100 ha) no sudeste do Brasil. Registraram-se as atividades alimentares de dois grupos usando a varredura instantânea durante um período de 13 meses. A dieta compôs-se de frutos, presas animais, cultivares, sementes, material vegetal e indeterminado. Os frutos foram consumidos mais na estação chuvosa do que na estação seca e o consumo de milho e cana atingiu um pico no início da estação seca. A proporção de frutos na dieta foi positivamente correlacionada com a intensidade de frutificação das árvores zoocóricas. A dieta vegetal incluiu 54 espécies, com milho, Rhamnidium elaeocarpus, Acrocomia aculeata, Guazuma ulmifolia e Cariniana, sendo os mais importantes. Embora a composição da dieta e a diversidade tenham sido similares a grupos de macacos-prego em grandes fragmentos florestais, o uso de cultivares atingiu altas porcentagens em épocas quando a produção de frutos zoocóricos foi baixa nos fragmentos.

PALAVRAS-CHAVE. Fragmentos de matas de galeria; Franca; milho; cana.

Capuchin monkeys, Cebus spp, occupy a wide spectrum of habitats where they feed on a variety of fruits, arthropods, and vertebrates. Tufted capuchin monkeys have been recorded in the wild in only a few sites (Zhang 1995, Di Bitteti et al. 2000, Sironello 2001, Izar 2004). They are difficult to habituate, and detailed dietary records are still scarce. Some studies focus on specific foods (e.g. bromeliads - Brown \& Zunino 1990; palm fruits - SPIRonello 1991; Cariniana seeds - Peres 1991; Ziziphus fruits - ZhANG \& WANG 1995; Araceae - VIEIRA \& IzAR 1999), and others relate plant part consumption with phenology (Galetti \& Pedroni 1994, Peres 1994, SteVEnSON et al. 2000). TERBORGH (1983) evaluated year-round variations in the abundance of the animals preyed upon.

Revista Brasileira de Zoologia 25 (1): 32-39, March, 2008 
Most of the information available on capuchins pertains to continuous forests. However, primate groups are persisting in small forest fragments (see CHIARELlo 2003), with unknown dietary consequences. With the reduction in food resources in forest fragments and the nearby abundance of field crops, recent studies in Africa report use of crops by primates (NAUGHTONTreves et al. 1998, Siex \& Struhsaker 1999, Hill 2000, Saj et al. 2001, Rugunda 2004). Chimpanzees, redtails and baboons are including banana, maize and sugar cane in their diets near Kibale National Park, Uganda (NAUghton-Treves et al. 1998).

Although primate studies in forest fragments are increasing in the Neotropics (Marsh 2003), studies of Cebus spp in such habitats continue to be uncommon (BROwn \& ZUNINO 1990, GALETTI \& Pedroni 1994). The large home range of Cebus spp (80 to 900 ha, Terborgh 1983, Robinson 1986, Zhang 1995, Di Bitteti 2001, SPIRONELLo 2001) suggests that the occupation of small forest fragments may challenge the adaptability of this primate genus.

This paper examines the diet of capuchins in small gallery forest fragments within an agricultural area. We identified and quantified the main food items throughout the year and related them to phenology, analysing seasonal variation and consumption of agricultural crops.

\section{MATERIAL AND METHODS}

The study was carried out in approximately 100 ha of interconnected gallery forests $\left(20^{\circ} 30^{\prime}-20^{\circ} 31^{\prime} 30^{\prime \prime} \mathrm{S}, 47^{\circ} 19^{\prime}-47^{\circ} 18^{\prime} \mathrm{W}\right)$ of the Ribeirão dos Correias and its tributaries, from the Santa Gemma farm and Maggion dairy cattle ranch, in the municipality of Franca, in northeastern São Paulo State. The study site also includes small bogs and contiguous hillside forests, with altitudes ranging from 800 to $1100 \mathrm{~m}$, interspersed with pastures and fields planted for silage.

Average monthly temperatures during the study period (July 2000 to July 2001) ranged from $17^{\circ} \mathrm{C}$ to $22^{\circ} \mathrm{C}$ in the dry and cold season (October to March) and from $21^{\circ} \mathrm{C}$ to $24^{\circ} \mathrm{C}$ in the wet and warm season (April to September). Rainfall ranged from $0.7 \mathrm{~mm}$ in June 2001 to $256 \mathrm{~mm}$ in January 2001, totaling $1283 \mathrm{~mm}, 20 \%$ less than the 10-year average $(1598 \mathrm{~mm}$, from 1992 to 2001; Instituto Nacional de Meteorologia, Sétimo Distrito, Franca, São Paulo).

Gallery and hillside forests in the area include average (8-12 $\mathrm{m}$ ) to large-sized ( $>25 \mathrm{~m}$ ) trees, understory bushes, and many lianas. Forest corridors are 30 to $200 \mathrm{~m}$ wide. Common species are Acrocomia aculeata (Jacq.) Lodd. (macaúba; Arecaceae), Cariniana estrelensis (Raddi) Kuntze (jequitibá; Lecythidaceae), Rhamnidium elaeocarpus Reissek (cafezinho; Rhamnaceae), and Ficus insipida Willd (Moraceae).

There are many species from the Leguminosae superfamily (Genera Andira, Acacia, Cassia, Inga, Hymenaea, Machaerium, Platycyanus, Senna), with abundant Inga edulis Mart. and Platycyanus regnelli Benth. The most common plant families are Meliaceae and Euphorbiaceae. In small bogs Euterpe edulis Mart. (Arecaceae), Pseudobombax grandiflorum (Cav.) A. Robins (ipê-do-brejo; Bombacaceae), Ficus insipida (Moraceae) and Talauma ovata A. St. - Hill (Magnoliaceae) predominate.

On the basis of six skins, VIEIRA $(1944,1955)$ considered capuchins from this region (Franca, northern São Paulo) to be a subspecies of C. libidinosus Spix, 1823 which is consistent geographically with RYLANDs et al. (2005). However the hypothesised existence of hybrids between Cebus apella nigritus Goldfuss, 1809 and Cebus apella libidinosus Spix, 1823 (KInsEy 1982) cannot be rejected. Vilanova et al. (2005) consider this region to contain either a transitional population of $C$. nigritus or the southern limit of $C$. libidinosus without consensus. We considered our study groups to be bearded capuchins, C. libidinosus.

Two capuchin monkey groups were followed. The larger one (L) was composed of 19 to 23 animals, including three adult males and six adult females, three subadults (one male and two females), seven juveniles and four infants born during the study period. It was followed for 15 days (132 h). The small group (S) was composed of 6 to 9 animals, including one adult male, three adult females, and two juveniles (one male and a female), as well as three infants born during the study period. It was followed for 58 days $(603 \mathrm{~h})$. The small group traveled more slowly and cohesively, favoring data collection.

After the three-month capuchin habituation period, the site was visited for one day each week from July 2000 to July 2001, and also for 15 consecutive days in July 2000 (dry season) and 18 days in January 2001 (wet season). Capuchins were followed from the time group members left their sleeping trees early in the morning (5:00-6:30 am) until they returned to their sleeping sites in the evening (6:00-8:00 pm).

Behaviors of the group members were recorded using instantaneous scan sampling (ALTMANn 1974, SeTz 1991). The first activity of each visible capuchin (except infants) was recorded at 10-min intervals between scans. Usually, at least six individuals were recorded in each scan. This is the total number of individuals in the small group, or a third of the individuals of the large group. When capuchins were feeding, we recorded the ingested item and species, and numbered and marked food trees and lianas with plastic flagging. Although we recorded animal matter ingestion, we did not include activities involved in finding food. Sampling animal behavior at established intervals yields an overall estimate of the amount of time spent in any given activity, such as feeding. Likewise, the proportion of feeding time that is spent on a particular food item (or food species) is considered to be indicative of the proportion of that item (or species) in the diet (Altmann 1974, Setz 1991).

Food items were classified as agricultural crops, fruits, seeds, flowers and nectar, other plant parts (shoots, leaf stems), animal and undetermined material. Specialists identified leftover animal parts (18\%). When parts were not available, animals seen in capuchin hands during consumption were identified to order or grouped as undetermined arthropods, or just animal matter. Proportions of monthly dietary items were compared between groups using Student's $t$ test.

Revista Brasileira de Zoologia 25 (1): 32-39, March, 2008 
For statistical analysis, both Wet (W) and Dry (D) seasons were separated into Early (E) and Late (L) parts (ED: from April to June; LD: from July to September; EW: from October to December; and LW: from January to March). We compared seasonal data using ANOVA on transformed proportions (arcsine from the square root, SOKAL \& ROHLF 1995), using the program BioEstat 4.0 (AYRES et al. 2005). Since proportions have a binomial rather than a normal distribution, this transformation is recommended to achieve normality and meet the assumptions required for parametric analyses of data (SOKAL \& RoHLF 1995).

For the phenological survey, 172 trees with Diameter at Breast Height $(\mathrm{DBH}) \geq 10 \mathrm{~cm}$ were marked randomly throughout the capuchin home range. From August 2000 to July 2001, these trees were monitored twice a month and records were made of the presence of flowers and flower buds, and both ripe and unripe fruits. Fruits were classified as zoochorous, anemochorous or autochorous. Spearman rank correlation analysis was performed to compare the proportions of fruit in the diet to the proportion of trees with zoochorous fruit in the phenological survey, also using BioEstat 4.0 (Ayres et al. 2005).

Food and phenology plant samples were collected and preliminarily identified with the help of a field guide (LoRENZI 1998). We sent samples to the Herbarium of the Escola Superior de Agronomia Luís de Queiroz (ESA - ESALQ) of the Universidade de São Paulo (USP) for confirmation of identification.

The amount of maize (Zea mays) lost to capuchins was estimated based on a conservative average consumption of one ear per adult capuchin per day for 180 days (the time for which maize was available) for three ears produced per plant, with four plants per square meter growing in an area of 25 ha.

\section{RESULTS}

The capuchin diet ( $\mathrm{N}=3998$ feeding records) included fruits $(47 \%)$, maize $(21 \%)$, sugar cane $(9 \%)$, seeds from native species
(5\%) and other plant life (5\%), including flower nectar, shoots, and petioles, animal matter (9\%), undetermined (4\%), either animal or plant parts, and 15 records $(<1 \%)$ in which capuchins were drinking water from tree holes or creeks. Since the home ranges of group $\mathrm{S}$ and group $\mathrm{L}$ overlapped completely and multiple comparisons did not show significant differences in dietary items, dietary data from the two groups were combined.

The plants in the diet included 54 species. Maize and sugar cane made up $32.4 \%$ of the plant diet. Capuchins also ate Rhamnidium elaeocarpus drupes (19.4\%), Acrocomia aculeata palm fruits (8.6\%), Guazuma ulmifolia globular fruits (6.5\%), Cariniana sp. (3.1\%) and Banisteriopsis sp. seeds (3\%; Tab. I).

Among animal items, capuchins ate mainly ants (12\%). We identified Zacryptocerus sp. (Formicinae) from nests in branch holes abandoned by the monkeys, and leaf-cutting ants (Attini) from parts observed in capuchin fecal samples. We identified wasp larvae and adults (4\%) of Polybia sp. and Metapolybia sp. (Polistidae), and bee larvae and honey (1\%) of Apis melifera (Apidae) from colonies destroyed by capuchins. Other arthropods were Arachnida (4\%), Lepidoptera (3\%), Orthoptera (2\%), Isoptera (1\%) and Diptera $(<1 \%)$. The vertebrates recorded consisted of two frogs, Itapotihyla langsdorffii and Scinax sp. (Hylidae), and a toad Chaunus schneideri (Bufonidae). Their consumption was only observed in the dry season (July 2001) and accounted for $1 \%$ of animal feeding records. Forty-one percent of arthropod and 30\% of other animal matter feeding records were not identified.

Capuchins consumed significantly more fruits in both EW (75\%) and LW (61\%) seasons (Fig. 1, vs. ED 15\% and LD 38\%, F $=5.50, \mathrm{p}<0.01)$. Fruits in the diet were positively correlated with fruiting intensity of zoochorous trees $\left(\mathrm{R}_{\mathrm{s}}=0.705, \mathrm{p}=0.01\right)$.

In the dry season, most of the fruits eaten were of Acrocomia aculeata and Guazuma ulmifolia, and the seeds were from Banisteriopsis spp and Cariniana estrelensis (25\%). Capuchins also ate figs (Ficus insipida) in three months of the dry season.

Table I. Plant families, species and plant parts, months of consumption and relative frequency in the plant diet of $C$. libidinosus in forest fragments in northeast São Paulo State, Brazil. (FI) Flower, (N) nectar, (Sh) shoot, (St) stem, (F) fruit, (P) pulp, (S) seed.

\begin{tabular}{|c|c|c|c|c|}
\hline Species & Family & Plant part & Month & Diet (\%) \\
\hline Zea mays* & Poaceae & $S$ & Dec-Jul & 22.9 \\
\hline Rhamnidium elaeocarpus & Rhamnaceae & $P, S$ & Dec-Feb & 19.5 \\
\hline Saccharum officinarum* & Poaceae & St & Jun-Sep, Dec & 9.4 \\
\hline Acrocomia aculeata & Arecaceae & $P$ & Apr-Jun, Sep-Jan & 8.6 \\
\hline Guazuma ulmifolia & Sterculiaceae & $\mathrm{F}, \mathrm{S}$ & Jun-Sep, Dec, Feb, May & 6.5 \\
\hline Psidium guajava & Myrtaceae & $\mathrm{F}, \mathrm{S}$ & Dec-Mar & 3.1 \\
\hline Banisteriopsis sp. & Malpighiaceae & $S$ & Jul-Sep & 3.0 \\
\hline Cariniana estrellensis & Lecythidaceae & $S$ & Jan-Sep & 2.8 \\
\hline Zanthoxylum rhoifolium & Rutaceae & $\mathrm{F}, \mathrm{S}$ & Jan-Mar & 2.8 \\
\hline Ficus insipida & Moraceae & $\mathrm{F}$ & Mar, May, Jul, Sep-Oct & 1.7 \\
\hline Urera baccifera & Urticaceae & $\mathrm{F}, \mathrm{S}$ & Feb-Apr & 1.4 \\
\hline Sp. 1 (liana) & Ulmaceae & $\mathrm{S}, \mathrm{Sh}, \mathrm{Fl}$ & Jan-Mar, Jul-Sep & 1.0 \\
\hline
\end{tabular}

Revista Brasileira de Zoologia 25 (1): 32-39, March, 2008 
Table I. Continued.

\begin{tabular}{|c|c|c|c|c|}
\hline Species & Family & Plant part & Month & Diet (\%) \\
\hline Senna multijuga & Caesalpiniaceae & $\mathrm{F}, \mathrm{S}$ & Jul-Sep & 0.9 \\
\hline Trichilia catigua + & Meliaceae & $\mathrm{F}$ & Oct-Dec & 0.9 \\
\hline Trichilia clausenii + & & $\mathrm{F}$ & & \\
\hline Trichilia elegans + & & $\mathrm{F}$ & & \\
\hline Trichilia hirta + & & $\mathrm{F}$ & & \\
\hline Merostaxis sp. & Poaceae & Sh, F, S & Dec-Feb, May, Jul & 0.7 \\
\hline Chorisia speciosa & Bombacaceae & $\mathrm{N}, \mathrm{FI}$ & Mar-May & 0.5 \\
\hline Sp. 2 & Ulmaceae & $\mathrm{F}, \mathrm{Sh}$ & Jul-Sep & 0.4 \\
\hline Allophyllus semiclathratus & Sapindaceae & $\mathrm{F}$ & Jan-Feb & 0.3 \\
\hline Cariniana legalis & Lecythidaceae & $S$ & Jul-Sep & 0.3 \\
\hline Ipomea cf. indica & Convolvulaceae & $\mathrm{N}, \mathrm{Fl}$ & Mar-May & 0.3 \\
\hline Pseudobombax grandiflorum & Bombacaceae & $\mathrm{N}, \mathrm{FI}$ & Jun-Jul & 0.3 \\
\hline Eucalyptus sp.* & Myrtaceae & $\mathrm{F}, \mathrm{S}, \mathrm{N}$ & May, Nov-Dec & 0.3 \\
\hline Inga edulis & Mimosaceae & $P$ & Jan-Feb & 0.2 \\
\hline Sp. 1 & Malpighiaceae & $\mathrm{F}, \mathrm{S}$ & Jul-Sep & 0.2 \\
\hline Daphnopsis fasciculata & Thymeleaceae & $\mathrm{F}, \mathrm{S}$ & Dec & 0.2 \\
\hline Luehea divaricata & Tiliaceae & $S$ & Jul & 0.2 \\
\hline Acacia paniculata & Mimosaceae & $\mathrm{N}, \mathrm{Fl}$ & Aug-Sep & 0.1 \\
\hline Albizia polycephala & Mimosaceae & $S$ & Aug-Sep. & 0.1 \\
\hline Citrus sp. (lime)* & Rutaceae & $P$ & May & 0.1 \\
\hline Croton floribundus & Euphorbiaceae & $\mathrm{F}$ & Jul-Sep & 0.1 \\
\hline Melia azedarach* & Meliaceae & $\mathrm{F}$ & May-Jun & 0.1 \\
\hline Momordica charantia & Cucurbitaceae & $S$ & Jan-Feb & 0.1 \\
\hline Pyrostegia venusta & Bignoniaceae & $\mathrm{N}, \mathrm{Fl}$ & Jul & 0.1 \\
\hline Syagrus romanzoffiana & Arecaceae & $P$ & Dec-Jan & 0.1 \\
\hline Annona cacans & Annonaceae & $P$ & May-Jul & $<0.1$ \\
\hline Casearia gossypiosperma & Flacourtiaceae & $\mathrm{F}$ & Dec & $<0.1$ \\
\hline Casearia obliqua & Flacourtiaceae & $\mathrm{F}$ & Jul-Aug & $<0.1$ \\
\hline Cecropia hololeuca & Cecropiaceae & $\mathrm{F}$ & Jun & $<0.1$ \\
\hline Enterolobium contortisiliquum & Mimosaceae & $\mathrm{F}$ & Jul & $<0.1$ \\
\hline Eugenia cf. sulcata & Myrtaceae & $\mathrm{F}, \mathrm{S}$ & Jul-Aug & $<0.1$ \\
\hline Eugenia ligustrina & Myrtaceae & $\mathrm{F}, \mathrm{S}$ & Jul-Aug & $<0.1$ \\
\hline Guarea guidonea & Meliaceae & $S$ & Oct-Nov & $<0.1$ \\
\hline Guarea kunthiana & Meliaceae & $S$ & Oct-Nov & $<0.1$ \\
\hline Guarea macrophylla & Meliaceae & $S$ & Oct-Nov & $<0.1$ \\
\hline Hymenaea courbaril & Caesalpiniaceae & $P$ & Jul-Aug & $<0.1$ \\
\hline Nectandra lanceolata & Lauraceae & $\mathrm{F}$ & Oct-Dec & $<0.1$ \\
\hline Nectandra megapotamica & Lauraceae & $\mathrm{F}$ & Oct-Dec & $<0.1$ \\
\hline Rollinia sylvatica & Annonaceae & $P$ & Jul-Sep & $<0.1$ \\
\hline Talauma ovata & Magnoliaceae & $S$ & Jul-Aug & $<0.1$ \\
\hline Xylopia aromatica & Annonaceae & $P$ & Jul & $<0.1$ \\
\hline Undetermined & Undetermined & Sh, F, S & Year-round & 9.8 \\
\hline
\end{tabular}

\footnotetext{
* Exotic species; + Identification of the trees showed that records for Trichilia were in fact for four species.
} 


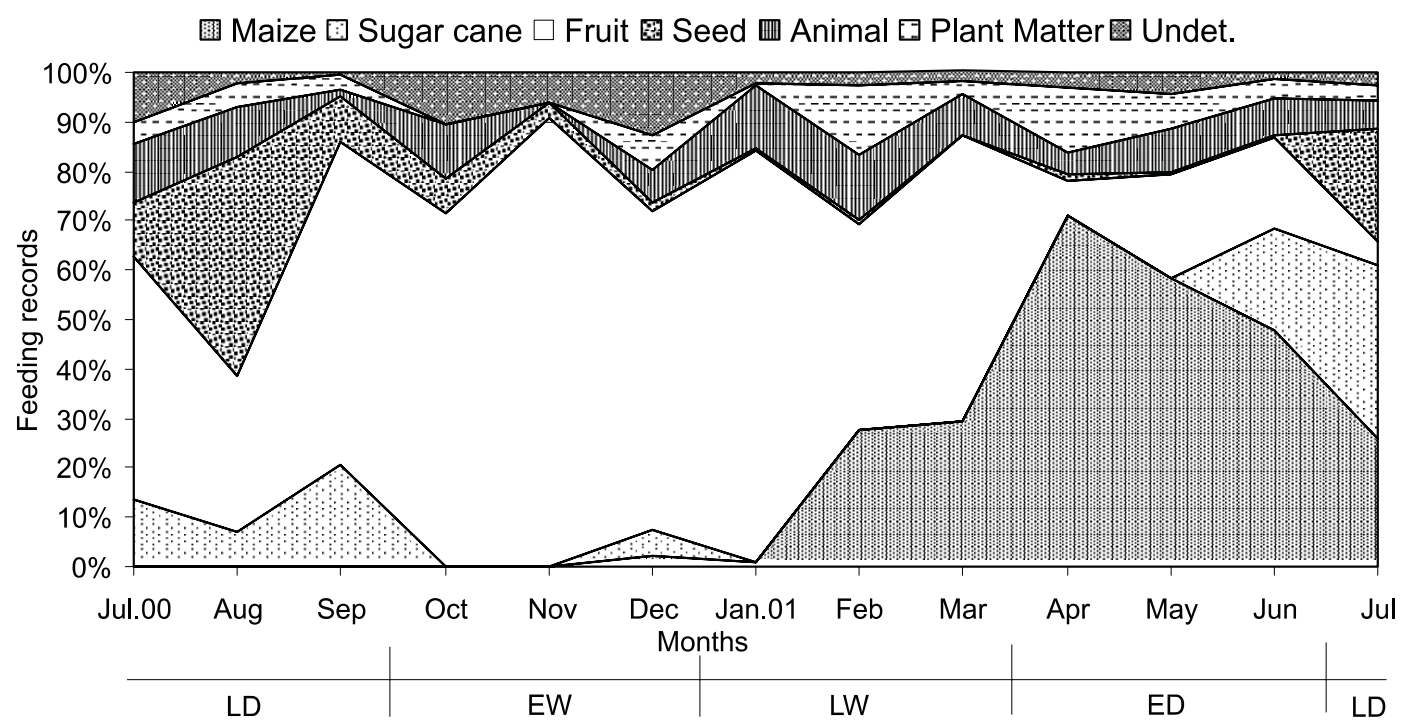

Figure 1. Monthly diet as proportion of feeding records of bearded capuchins throughout the study period in northeast São Paulo, Brazil. (LD) Late dry, (EW) early wet, (LW) late wet, (ED) early dry.

In the wet season, the species most visited for fruits were Rhamnidium elaeocarpus, Acrocomia aculeata and Psidium guajava, which together made up 55\% of wet season records.

Maize and sugar cane made up about 30\% of the $C$. libidinosus diet, varying monthly from $71 \%$ in the dry season to $0 \%$ in the wet season. Agricultural crops in the diet were negatively correlated with fruiting intensity of zoochorous trees $\left(\mathrm{R}_{\mathrm{S}}=-0.624 ; \mathrm{p}=0.03\right)$. Maize loss to capuchins was estimated as $0.15 \%$ of production. Capuchins ate maize from both fields, and also ate harvest leftovers, when they risked exposing themselves in open fields. Capuchins consumed significantly more crop items in the ED season (59\% vs. 1-19\% for other seasons, $\mathrm{F}=9.75, \mathrm{p}<0.005)$. Sugar cane was available year-round, but capuchins consumed it most in the LD season (19\% vs. $0-7 \%$ for other seasons, $\mathrm{F}=4.47, \mathrm{p}<0.05$ ), when they spent much time sucking sugar cane piths, and consumed less water. From July to September 2000, when no maize was available, sugar cane represented $14 \%$ of all food records.

Native seeds (excluding maize) constituted 10\% and 9\% of the diet in the dry and wet seasons, respectively, with a peak in August (44\% of monthly feeding records) due to Cariniana spp seeds. LD season months showed the highest consumption of seeds, averaging $18 \%$ of the monthly feeding records, when maize was not available. In July 2001, besides leftover maize, other seeds made up $23 \%$ of the diet, twice the percentage of July 2000 without maize (11\%, Fig. 1).

\section{DISCUSSION}

Environmental factors such as the presence of abundant resources, productivity of some plant species, marked seasonal variation, insect abundance and a number of competitor spe- cies are determinants of diet composition for tufted capuchins (Terborgh 1983, Brown \& Zunino 1990, Peres 1991, Stevenson et al. 2000). Our study recorded the presence of abundant cultivated resources (such as maize and sugar cane), extended productivity of $A$. aculeata, and marked seasonal variation of some plant species, such as R. elaeocarpus, G. ulmifolia, P. guajava and C. estrelensis. Despite the small size of the forest fragment, dietary plant richness (54 vs. 71 species) and fruit consumption (47 vs. $54 \%$ ) were not so different from another study on capuchins in a larger fragment ( $250 \mathrm{ha}$ ) from southeast Brazil (GALETTI \& Pedroni 1994). These findings also agree with the contention that most animals that forage on crops (in our study the highest and third highest percentages were for crops) do not forgo wild foods, but instead add crops to their other foraging activities (see Naughton-Treves et al. 1998).

Animal consumption by capuchins also varies greatly in forest fragments (9.5-20\%, FreEse \& OpPenheIMER 1981, present study) as well as in continuous forest (17-75\%, TERBORGH 1983, SPIRONELlo 1991, IZAR 2004). Low animal consumption in an area of high edge proportion, such as gallery forests in Franca, is contrary to the expectation of high insect abundance at forest edges, as reported in the general literature (Goвв \& Zucchi 1985, Fowler et al. 1993, Didham 1997). It is possible that this reduced insect proportion in the diet is in part compensated for by the high consumption of maize, due to its elevated protein and sodium content (9.3\% protein; Freitas et al. 2005).

Similar to that observed elsewhere, there was a significant correlation between fruits in the diet and zoochorous fruits in phenology (Terborgh 1983, Zhang 1995, but see Stevenson et al. 2000). In highly seasonal environments, fruit phenology determines significant seasonal variation in the diet of Cebus spp 
(Terborgh 1983, Robinson 1986, Brown \& Zunino 1990, Galetti \& Pedroni 1994, Peres 1994, Zhang 1995, but see Stevenson et al. 2000). In the dry season Cebus is obliged to concentrate on just a few key plant species (Terborgh 1983, Brown \& Zunino 1990, Sirronello 1991, Peres 1994). The present study shows that maize and sugar cane are the main sources of food for capuchins in the dry season. Crop use is also reported during the dry season in Old World monkeys (Naughton-Treves et al. 1998, Hill 2000).

Maize and sugar cane have already been reported in the capuchin diet (Freese \& Oppenheimer 1981, Galetti \& Pedroni 1994, Siemers 2000). The contribution of agricultural crops varies among forest fragments (14-30\%, Galetti \& Pedroni 1994, this study) but it is not directly related to fragment size in southeastern Brazil. Its seasonal importance (up to 71\%) in this small forest fragment in Franca is remarkable. To the best of our knowledge, there is no report of other Neotropical primate species raiding crops in the same way as those of the Old World (Naughton-Treves et al. 1998, Hill 2000, SAj et al. 2001, Rugunda 2004). According to Brown \& Zunino (1990), the ability of Cebus to explore resources not accessible to other primate species is one of the reasons for its wide geographical distribution and occurrence in marginal ecosystems.

Capuchins are in the lower limit of weight $(3 \mathrm{~kg})$ and group size (6-30 individuals) of the Old World primates that use crops (3.5-60 kg, 5-140 ind., Freese \& Oppenheimer 1981, Rowe 1996). The farmers explain that capuchins only eat corncobs from the plantation edge and C. H. Freitas observed that capuchins gathered leftover cobs on the ground after the silage machine had cut down maize plants. In this region, in particular, maize plants are used for silage. Therefore economic losses were minimal (< $1 \%)$. If there was a dependence on agriculture for human subsistence, such as in Africa (Naughton-Treves et al. 1998, Hill 2000, SAJ et al. 2001, RUGUNDA 2004), capuchin maize and sugar cane consumption could cause larger amounts of damage.

During a period of 13 months, we recorded seven out of nine adult females giving birth between the late dry and late wet season. Considering an interbirth interval of $19.35 \mathrm{mo}$ (Di ВітTETI $\&$ JANSON 2001), the number of births would be 0.63 infants per female per year, similar to Di Biтteti \& Janson's (2001) estimates of 0.59 or 0.61 for unprovisioned and provisioned groups, respectively. These data show no reduction in reproduction.

In summary, although average dietary composition and diversity were similar to those of capuchins in larger forest fragments, in this study, feeding on crops attained higher percentages at times when zoochorous fruit production was low in these small fragments.

Since this data shows no reduction in reproduction, it is likely, therefore, that agricultural crops are not only helping capuchin survival in a fragmented landscape, but could also favour a population increase. A population increase could turn them into pests and start conflicts with farmers.

Because of this, we suggest some measures that could reduce the problem, like to plant trees that ripen in dry season or have extended productivity, like Cariniana spp, Guazuma ulmifolia and Acrocomia aculeata, promoting at the same time the enlargement of the gallery forests corridors and the maintenance of bearded capuchins inside of fragments.

Beyond this, it's necessary to inform the farmers about the importance of monitoring and managing cultivated areas (Naughton-Treves et al. 1998, Hill 2000, SAj et al. 2001), with regards to the bearded capuchins conservation in the forest. For this reason, maize and sugar cane should be cultivated far from the forest fragments and near the properties, making animal access difficult (see $S_{\mathrm{Aj}}$ et al. 2001, Rugunda 2004). In extreme situations, a monoculture that is not attractive to primates (eg. tea or coffee) could be cultivated in the edge (NAughton-Treves 1998) or until a reintroduction of predators could be a good option (Rocha 2000).

An interesting fact is that in a further site visit on February 2005 , the farmers were interviwed and didn't mention having any problem with capuchins. This information, allied to a recent discovery about the use of stone tools to crack coconuts (WAGA et al. 2006) and even the cassava consumption (LudwIG et al. 2006), pointing to a great capuchins diet plasticity, makes its species apt to survive in a extensive variety of habitats, besides anthropic environments, where the capuchins make opportunistic use of human cultivated plants.

\section{ACKNOWLEDGMENTS}

The study was concluded with resources and support of UNESP, UNICAMP and UNIFRAN universities. CHF was supported by the Centro Universitário do Planalto de Araxá during the final stages of this research.We are grateful to Orlando Cintra and Vínio Maggion, owners of Fazenda Santa Gemma and Agropecuaria Maggion, respectively, for the permission to do research on the farms. Denizar Freitas provided dedicated field assistance and invaluable encouragement during all research stages. We thank José Luís and Cláudio Dias, field assistants, for help during data sampling. R.R. Rodrigues and A.A. Arantes for plant identification, and A.E.C. Farinha, for insect identification. We thank W. Spironello for comments on earlier versions of this manuscript. A. Chiarello, Colin Chapman, P. Izar, W. W. Benson and one anonymous reviewer for helpful comments on the manuscript.

\section{LITERATURE CITED}

Altmann, J. 1974. Observational study of behavior: Sampling methods. Behaviour 49: 227-267.

Ayres, M.; M. Ayres Jr; D.L. Ayres \& A.S. Santos. 2005. BioEstat 4.0: Aplicações estatísticas nas áreas das ciências biológicas e médicas. Belém, Sociedade Civil Mamirauá, CNPq.

Brown, A.D. \& G.E. Zunino. 1990. Dietary Variability in Cebus apella in extreme habitats: evidence for adaptability. Folia Primatologica 54: 187-195.

Chiarello, A.G. 2003. Primates of the Brazilian Atlantic Forest: the influence of forest fragmentation on survival, p. 99-121. In: L. MARSh (Ed.). Primates in fragments: ecology and 
conservation. New York, Kluwer Academic, Plenum Publishers, XXIV+428p.

Di BitTeti, M.S. 2001. Home-range use by the tufted capuchin monkeys (Cebus apella nigritus) in a subtropical rainforest of Argentina. Journal of Zoology (London) 253: 33-45.

Di BitTeti, M.S. \& C.H. JAnson. 2001. Reproductive socioecology of tufted capuchins (Cebus apella nigritus) in northeastern Argentina. International Journal of Primatology 22: 127-142.

Di Bitteti, M.S.; E.M.L.Vidal; M.C. Baldovino \& V. Benesovsky. 2000. Sleeping site preferences in tufted capuchin monkeys (Cebus apella nigritus). American Journal of Primatology 50: 257-274.

Didham, R.K. 1997. An overview of invertebrate responses to forest fragmentation, p. 303-320. In: A. WATT; N.E. STORK \& M. Hunter (Eds). Forests and insects. London, Chapman and Hall, XIII+424p.

Fowler, H.G.; C.A. Silva \& E.M. VenticinQue. 1993. Size, taxonomy and biomass distributions of flying insects in Central Amazônia: forest edge vs. understory. Revista de Biologia Tropical 41: 755-760.

Freese, C.H. \& J.R. OpPenheImer. 1981. The capuchin monkeys, genus Cebus, p. 331-390. In: A.F. Coimbra-Filho, \& R.A. Mittermeier (Eds).Ecology and behaviour of Neotropical Primates. Rio de Janeiro, Academia Brasileira de Ciências, vol. 1, 496p.

Freitas, E.R.; N.K. Sakomura; R. Neme \& N.A.A.Barbosa. 2005. Valor nutricional do milho termicamente processado, usado na ração pré-inicial para frangos de corte. Arquivo Brasileiro de Medicina Veterinária e Zootecnia 57: 510-517.

Galetti, M. \& F. Pedroni. 1994. Seasonal diet of capuchin monkeys (Cebus apella) in a semideciduous forest in south-east Brazil. Journal of Tropical Ecology 10: 27-39.

Goвbi, N. \& R. Zucchi. 1985. On the ecology of Polistes versicolor versicolor (Oliver) in southern Brazil (Hymenoptera, Vespidae, Polistini) II: Colonial productivity. Naturalia 10: 21-25.

HiLl, C.M. 2000. Conflict of interest between people and baboons: Crop raiding in Uganda. International Journal of Primatology 21: 299-315.

IzAR, P. 2004. Female social relationships of Cebus apella nigritus in a southeastern Atlantic forest: an analysis through ecological models of primate social evolution. Behaviour 141: 71-99.

KInsey, W.G. 1982. Distribution of Primates and Forest Refuges, p. 455-482. In: G.T. PRANCE (Ed.). Biological Diversification in the tropics. New York, Columbia University Press, 714p.

LorenzI, H. 1998. Árvores brasileiras. Nova Odessa, Instituto Plantarum de Estudos da Flora, vol. 1, $2^{\mathrm{a}}$ ed., 352p.

Ludwig, G.; L.M. Aguiar \& V.J. Rocha. 2006. Comportamento de obtenção de Manihot esculenta Crantz (Euphorbiaceae), mandioca, por Cebus nigritus (Goldfuss) (Primates, Cebidae) como uma adaptação alimentar em períodos de escassez. Revista Brasileira de Zoologia 23 (3): 888-890.

Marsh, L. 2003. Primates in fragments: ecology and conservation. New York, Kluwer Academic, Plenum
Publishers, XXIV+428p.

Naughton-Treves, L. 1998. Predicting patterns of crop damage by wildlife around Kibale National park, Uganda. Conservation Biology 12: 156-168.

Naughton-Treves, L.; A. Treves; C. Chapman \& R. Wrangham. 1998. Temporal patterns of crop-raiding by primates: linking food availability in croplands and adjacent forest. Journal of Applied Ecology 35: 596-606.

Peres, C.A. 1991. Seed predation of Cariniana micrantha (Lecythidaceae) by brown capuchin monkeys in central Amazônia. Biotropica 23: 262-270.

Peres, C.A. 1994. Primate responses to phenological changes in an Amazonian terra firme forest. Biotropica 26: 98-112.

Robinson, J.G. 1986. Seasonal variation in use of time and space by the wedge-capped capuchin monkey, Cebus olivaceus: Implications for foraging theory. Smithsonian Contributions to Zoology 431: 1-60.

RocHA, V.J. 2000. Macaco-prego, como controlar esta nova praga florestal? Floresta 30 (1/2): 95-99.

Rowe, N. 1996. The pictorial guide to the living primates. New York, Pogonias Press, VIII+263p.

Rugunda, G.K. 2004. Crop raiding around Lake Mburo National Park, Uganda. African Journal of Ecology 42: 32-41.

Rylands, A.B.; M.C.M. KierulfF \& R.A. Mittermeier. 2005. Notes on the taxonomy and distributions of the tufted capuchin monkeys (Cebus, Cebidae) of South America. Lundiana 6 (Suppl.): 97-110.

SaJ, T.L.; P. Sicotte \& J. D. Paterson. 2001. The conflict between vervet monkeys and farmers at the forest edge in Entebbe, Uganda. African Journal of Ecology 39: 195-199.

SETZ, E.Z.F. 1991. Métodos de quantificação de comportamento de primatas em estudo de campo, p. 411-436. In: A.B. Rylands, \& A.T. Bernardes (Eds). A Primatologia no Brasil. Belo Horizonte, Fundação Biodiversitas, vol. 3, 459p.

Siemers, B.M. 2000. Seasonal variation in food resource and forest strata use by brown capuchin monkeys (Cebus apella) in a disturbed forest fragment. Folia Primatologica 71: 181-184.

Siex, K.S. \& T.T. StruhsaKer. 1999. Colobus monkeys and coconuts: a study of perceived human-wildlife conflicts. Journal of Applied Ecology 36: 1009-1020.

SoKal, R.R. \& F.J. Rohlf. 1995. Biometry. New York, W. H. Freeman, 880p.

Spironello, W.R. 1991. Importância dos frutos de palmeiras (Palmae) na dieta de um grupo de Cebus apella (Cebidae, Primates) na Amazônia Central, p. 285-296. In: A.B. RyLANDS, \& A.T. Bernardes (Eds). A Primatologia no Brasil. Belo Horizonte, Fundação Biodiversitas, vol. 3, 459p.

Spironello, W.R. 2001. The brown capuchin monkey (Cebus apella), p. 271-283. In: R.O. BierregaARD JR; C. Gascon; T.E. Lovejoy \& R. Mesquita. (Eds). Lessons from Amazonia. New Haven, Yale University Press, 496p.

Stevenson, P.R.; M.J. Quinones \& J.A. Ahumada. 2000. Influence of fruit availability on ecological overlap among four Neotro- 
pical primates at Tinigua National Park, Colombia. Biotropica 32: $533-544$.

Terborgh, J. 1983. Five New World Primates - A study in comparative ecology. Princeton, Princeton University Press, XIV+260p.

Vieira, C.C. 1944. Os símios do estado de São Paulo. Papéis Avulsos de Zoologia 4: 1-31.

Vieira, C.C. 1955. Lista remissiva dos mamíferos do Brasil. Arquivos de Zoologia 8: 341-474.

VieIRA, E.M. \& P. IzAR. 1999. Interactions between aroids and arboreal mammals in the Brazilian Atlantic rainforest. Plant Ecology 145: 75-82.

Vilanova, R.; J.S. Silva Júnior; C.E.V. Grelle; G. Marroig \& R.
Cerqueira. 2005. Limites climáticos e vegetacionais das distribuições de Cebus nigritus e Cebus robustus (Cebinae, Platyrrhini). Neotropical Primates 13: 14-19.

Waga, I.C.; A.K. Dacier; P.S. Pinha \& M.C.H. Tavares. 2006. Spontaneous tool use by wild capuchin monkeys (Cebus libidinosus) in the cerrado. Folia Primatologica 77: 337-344. ZHANG, S.Y. 1995. Activity and ranging patterns in relation to fruit utilization by brown capuchins (Cebus apella) in French Guiana. International Journal of Primatology 16: 489-507. ZHANG, S.Y. \& L.X.WANG. 1995. Fruit consumption and seed dispersal of Ziziphus cinnamomum (Rhamnaceae) by two simpatric Primates (Cebus apella and Ateles paniscus) in French Guiana. Biotropica 27: 397-401.

Received in 20.VI.2007; accepted in 29.II.2008. 